\title{
PENGARUH LINGKUNGAN KERJA, SELF-EFFICACY, DAN KARAKTERISTIK PESERTA PELATIHAN TERHADAP TRANSFER PELATIHAN KARYAWAN
}

\author{
YUPITER GULO \\ NURTI WIDAYATI \\ Trisakti School of Management, Jl. Kyai Tapa No. 20 Jakarta Barat - Indonesia \\ yupiter@stietrisakti.ac.id, nurti@stietrisakti.ac.id
}

\begin{abstract}
The purpose of this study was to determine the effect of the work environment, self-efficacy, and characteristics of trainees on the transfer of training. Research conducted on the employees of PT. PJB UP Muara Tawar, a subsidiary of PLN, by taking 90 employees as research samples using purposive sampling technique. To analyze data collected using Multiple Linear Regression to prove the research hypothesis. Based on the studies conducted, the results of the analysis show that the work environment, self-efficacy, and characteristics of trainees significantly influence the direction of the training transfer. For this reason, it is suggested that the company pay attention to the work environment, self-efficacy, and characteristics of employee training participants. With the intention of employees can transfer training well and do what has been learned at the training site into work every day.
\end{abstract}

Keywords: Lingkungan kerja, self-efficacy, karakteristik peserta pelatihan, transfer pelatihan.

Abstrak: Tujuan penelitian adalah untuk mengetahui pengaruh lingkungan kerja, self-efficacy, dan karakteristik peserta pelatihan terhadap transfer pelatihan. Penelitian yang dilakukan ini pada karyawan PT. PJB UP Muara Tawar, anak perusahaan PLN, dengan mengambil 90 orang karyawan sebagai sampel penelitian dengan teknik purposive sampling. Untuk menganalisi data yang dikumpulkan menggunakan Regresi Linier Berganda untuk membuktikan hipotesa penelitian. Berdasarkan kajian yang dilakukan, maka hasil analisis menunjukkan bahwa variabel lingkungan kerja, self-efficacy, dan karakteristik peserta pelatihan berpengaruh secara signifikan dan arahnya positif terhadap transfer pelatihan. Untuk itu, disaankan agar perusahaan memberikan perhatian pada lingkungan kerja, self-efficacy, dan karakteristik peserta pelatihan karyawan. Dengan maksud karyawan dapat melakukan transfer pelatihan dengan baik dan melakukan yang sudah dipelajari di tempat pelatihan ke dalam pekerjaan setiap hari.

Kata kunci: Lingkungan kerja, self-efficacy, karakteristik peserta pelatihan, transfer pelatihan.

\section{PENDAHULUAN}

PT PLN yang merupakan perusahaan monopoli dalam menyediakan listrik bagi Indonesia memiliki peran yang sangat penting, terutama melalui anak perusahaannya yaityu PT Pembangkitan Jawa-Bali (PJB) yang sudah berdiri pada tahun 1995 dan secara tidak langsung mendorong perkembangan perekonomian nasional dengan menyediakan energi listrik yang handal dan ramah lingkungan. Dengan visi menjadi perusahaan pembangkit tenaga listrik Indonesia yang terkemuka dengan standar kelas dunia, BPJ terus berbenah melakukan inovasi dengan tetap berpegang 
pada tata pengelolaan perusahaan yang baik, Good Corporate Governance atau GCG yang mendasari suatu proses dan mekanisme pengelolaan perusahaan berlandaskan peraturan perundangundangan dan etika berusaha.

Perusahaan memperlihatkan kinerja yang baik hingga tahun 2016, sebagian besar telah berjalan baik dan sesuai dengan target, meskipun masih ada beberapa pembangkit yang perlu ditingkatkan kinerjanya. Keadaan ini tercermin dari kinerja sembilan Unit Pembangkitan yang dimiliki dengan kapasitas total 7.055 MW dan tujuh pembangkit milik PT PLN yang pengelolaannya diserahkan pada perusahaan dengan kapasitas 4.605 MW. Tercatat tahun 2016, kesiapan unit pembangkit eksisting mampu mencapai 1,54\% lebih tinggi dari RKAP 2016. Realisasi produksi energi listrik menunjukkan pertumbuhan $1,23 \%$ dibanding tahun sebelumnya dan mencapai $100,41 \%$ dari RKAP 2016. Selain itu, realisasi penjualan energi listrik mengalami pertumbuhan 1,36\% dibanding tahun sebelumnya dan mencapai $100,95 \%$ dari RKAP 2016, seperti tergambar pada grafik berikut ini.

\section{Penjualan Energi Listrik Unit Eksisting}

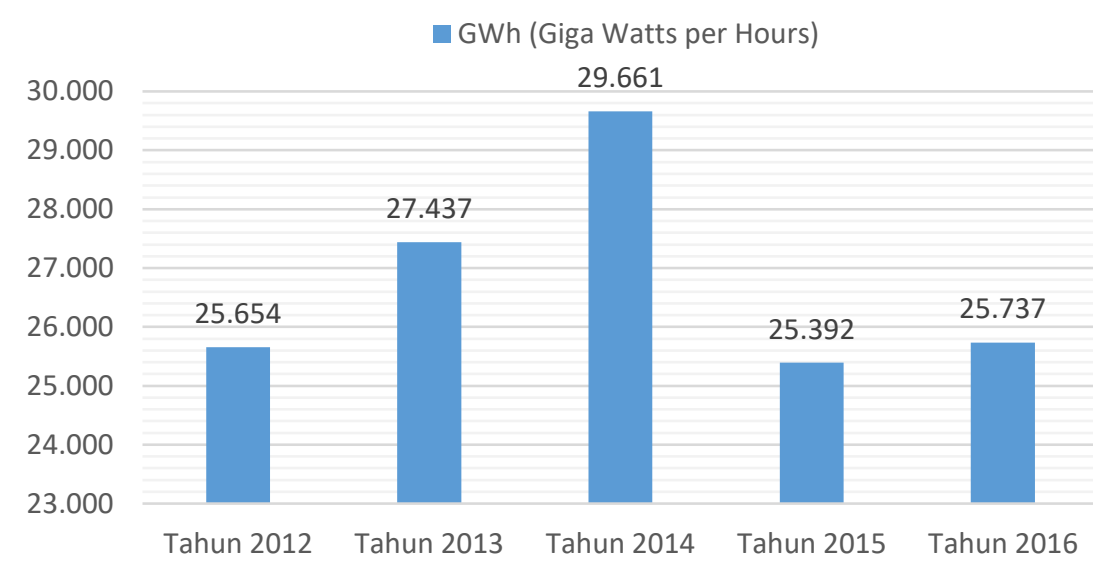

Gambar 1. Penjualan Energi Listrik Unit Eksisting Tahun 2012 - 2016 Sumber; Laporan keuangan 2016 PT PJB UP Muara Tawar

Penyebab munculnya dilakukanya transfer pelatihan pada perusahaan, karena sebagai perusahaan yang bergerak di sektor pembangkitan tentu mengambil peran mendukung upaya Pemerintah dalam memproduksi listrik demi mencukupi kebutuhan listrik nasional. Hingga saat ini, terus memaksimalkan Unit-Unit Pembangkitan yang dimilikinya ditambah dengan beberapa pembangkit milik PLN yang operasi serta pemeliharaannya diserahkan pada PJB. Nampak, penjualan listrik berdasarkan buku tahunan pada tahun 2012 mencapai sebesar 25,654 GWh. Sedangkan pada tahun 2014 mengalami peningkatan sebesar 29,661 GWh dibandingkan dengan tahun sebelumnya sebesar 27,437 GWh. Sedangkan pada tahun 2015 mengalami penurunan penjualan sebesar 4,269 $\mathrm{GWh}$ menjadi 25,392 GWh, lalu di tahun 2016 mengalami peningkatan $0,345 \mathrm{GWh}$ menjadi 25,737 GWh.

Untuk itu menarik untuk diteliti pengaruh transfer pelatihan, karena dalam menjalankan operasional perusahaan ini mengandalkan kualitas karyawan yang 
mampu menjalankan tanggung jawab yang diberikan oleh perusahaan, maka diharapkan para karyawan selalu memanfaatkan setiap waktu yang ada untuk melakukan tugastugas dengan efisien untuk menciptakan kinerja yang baik untuk mencapai tujuan yang diharapkan. Berdasarkan hasil penelitian terdahulu yang dilakukan oleh Kimbal dan Rahyuda (2015) dalam penelitiannya menunjukan adanya pengaruh positif lingkungan kerja terhadap transfer pelatihan. Pengaruh positif ini berarti apabila lingkungan kerja baik dan mendukung karyawan, maka karyawan dapat melakukan transfer pelatihan. Sedangkan menurut Gita dan Sariyathi (2016) melakukan penelitian dengan hasil menunjukkan bahwa variabel lingkungan kerja memberikan pengaruh positif terhadap transfer pelatihan sebesar 0,334 .

Penelitian sebelumnya yang dilakukan oleh Kimbal dan Rahyuda (2015) mengatakan bahwa Self - Efficacy memiliki pengaruh signifikan dan positif terhadap transfer pelatihan. Pengaruh signifikan dan positif berarti apabila karyawan memiliki self - efficacy yang tinggi maka mereka akan mampu melakukan transfer pelatihan dengan maksimal dan sebaliknya. Sedangkan menurut Gita dan Sariyathi (2016) melakukan penelitian dengan hasil Variabel self-efficacy memberikan pengaruh signifikan dan positif terhadap transfer pelatihan karyawan PT. Indonesia Power UPJP Bali,Pesanggaran sebesar 0,311.

Berdasarkan penelitian yang dilakukan oleh Gita dan Sariyathi (2016) melakukan penelitian dengan Variabel Karakteristik karyawan yang menunjukan pengaruh signifikan dan positif terhadap transfer pelatihan karyawan PT. Indonesia Power UPJP Bali Pesanggaran sebesar 0,342 . Sedangkan hasil sebelumnya yang dilakukan oleh Ahmad (2013) menyatakan bahwa karakteristik peserta pelatihan berpengaruh signifikan dan positif terhadap transfer pelatihan hasil pengujian hipotesis menunjukkan bahwa karakteristik peserta pelatihan berpengaruh siginifikan dan positif terhadap transfer pelatihan. Hasil ini memiliki arti semakin baik karakteristik peserta pelatihan yang dimiliki oleh karyawan maka karyawan dapat melakukan hasil pelatihan dengan baik.

Hasil penelitian jurnal lain yang diteliti oleh Melody Ling-Yu Wen dan Danny YungChuan (2014) dengan jurnal berjudul Trainees' Characteristics in Training Transfer The Relationship among Self-Efficacy, Motivation to Learn, Motivation to Transfer and Training Transfer dengan menggunakan objek Industri di Taiwan yang memiliki 500 populasi dan sampel. Dengan hasil penelitian tersebut tidak terdapat pengaruh signifikan dan negatif terhadap self-efficacy terhadap transfer pelatihan. Rekomendasi yang diberikan pada jurnal ini yaitu menggunakan variabel bebas lainnya yang berhubungan transfer pelatihan serta dalam pengumpulan data untuk penelitian selanjutnya melakukan wawancara dengan pertanyaan yang telah disiapkan.

\section{Transfer Pelatihan}

Tujuan akhir dari setiap program pelatihan adalah bahwa belajar yang terjadi selama pelatihan ditransfer kembali ke dalam pekerjaan. Transfer pelatihan (transfer of training) didefinisikan sejauh mana, pengetahuan, keahlian dan perilaku belajar dalam pelatihan diterapkan dalam pekerjaan (Noe, et al., 2003). Definisi lain diberikan pada istilah transfer pelatihan, diantaranya pendapat dari Baldwin dan Ford (2008). Transfer positif dari pelatihan adalah sejauh mana peserta pelatihan secara efektif menerapkan pengetahuan, keterampilan, dan sikap yang diperoleh di dalam konteks pelatihan yang deiberikan untuk pekerjaan. Menurut Broad \& Newstrom dalam Suhartono dan Raharso (2003) Transfer pelatihan adalah penerapan yang efektif dan berkelanjutan, oleh peserta 
pelatihan di terapkan untuk pekerjaan mereka, pengetahuan dan keterampilan dapat diperoleh dalam pelatihan - baik di dalam maupun di luar pekerjaan.

\section{Lingkungan Kerja}

Lingkungan Kerja merupakan semua yang terdapat di sekitar tempat kerja yang dapat mempengaruhi pegawai baik secara langsung maupun tidak langsung (Sedarmayanti 2011 :23). Menurut Simanjuntak (2013, 39) lingkungan kerja merupakan keseluruhan alat perkakas yang dihadapi, lingkungan sekitarnya dimana seseorang bekerja, metode kerjanya, serta pengaturan kerjanya baik sebagai perseorangan maupun sebagai kelompok. Menurut Hariyatie (2005) Lingkungan kerja adalah tanggapan peserta terhadap lingkungan tempat masing-masing peserta bekerja, berkaitan dengan aktivitas pelatihan yang mereka ikuti dan penerapannya, Maka uraian diatas menyimpulkan bahwa lingkungan kerja adalah segala sesuatu yang ada di sekitar para pekerja dapat mempengaruhi karyawan dalam melaksanakan suatu pekerjaan.

$\mathrm{H}_{1}$ Terdapat pengaruh lingkunagn kerja terhadap transfer pelatihan.

\section{Self-Efficacy}

Menurut Robbin and Judge $(2016,258)$ keyakinan individu bahwa ia mampu mengerjakan suatu tugas. Menurut Kreitner dan Kinicki $(2014,125)$ keyakinan seseorang mengenai peluang keberhasilannya dalam menyelesaikan pekerjaan tertentu. Menurut Moorhead dan Griffin $(2013,149)$ tingkat dimana kita percaya kita dapat mencapai sasaran kita meskipun kita pernah gagal pada masa lalu. Maka kesimpulan diatas adalah self efficacy merupakan keyakinan individu bahwa mereka dapat menyelesaikan tugasnya dengan melihat peluang keberhasilan yang ada walaupun mereka pernah gagal di masa lalu
$\mathrm{H}_{2}$ : Terdapat pengaruh self-efficacy terhadap transfer karyawan.

\section{Karakteristik Peserta Pelatihan}

Karakteristik peserta pelatihan adalah kepribadian peserta pelatihan secara langsung mempengaruhi proses pelatihan dan transfer pelatihan. Hal ini juga mengacu pada kemampuan seseorang untuk belajar, mensintesis, dan menghubungkan apa yang telah ia pelajari untuk berlatih dan mentransfer keterampilan dan pengetahuan untuk bekerja (Yusof, 2012). Ford et al. (1997) ,Blume et al. (2010), dan Ahmad (2013) karakteristik peserta pelatihan meliputi kemampuan, keterampilan, motivasi, dan faktor kepribadian peserta.Karakteristik peserta pelatihan adalah berbagai persepsi orang-orang yang dilatih tentang karakteristik-karakteristik lingkungan pelatihan dan pekerjaan yang mempengaruhi keyakinan mereka untuk bisa menerapkan hasil-hasil pelatihan pada pekerjaan. Menurut Baldwin dan Ford $(1988,65)$, karakteristik peserta, misalnya kecakapan, kepribadian, dan motivasi merupakan faktor penting, baik langsung maupun tidak langsung mempengaruhi keberhasilan suatu transfer pelatihan. Maka kesimpulananya adalah peserta pelatihan yang mempunyai keinginan untuk berprestasi akan cenderung untuk mengaplikasikan apa yang ia peroleh dari suatu pelatihan.

$\mathrm{H}_{3}$ Terdapat pengaruh karakteristik peserta pelatihan terhadap transfer karyawan.

\section{METODE PENELITIAN}

Bentuk penelitian yang akan
digunakan merupakan kausalitas, yaitu
penelitian yang menguji sebab akibat antara
variabel independen terhadap variabel
dependen (Sekaran dan Bougie 2013, 98).
Penelitian ini dilakukan dengan tujuan untuk
mengetahui apakah terdapat pengaruh antara
Lingkungan kerja, Self Efficacy, Karakteristik


Peserta Pelatihan terhadap Transfer Pelatihan Karyawan. Dengan memilih perusahaan sebagai objek penelitian ini sekaligus karyawan sebagai populasi penelitian. Sugiyono (2015, 148) menyatakan bahwa, populasi merupakan wilayah generalisasi yang terdiri atas objek/subjek yang mempunyai kualitas dan karakteristik tertentu yang ditetapkan oleh peneliti untuk dipelajari dan kemudian ditarik kesimpulannya, yang terdiri dari sekitar 290 karyawan dalam perusahaan obyek penelitian.

Teknik pengambilan sampel yang digunakan dalam penelitian ini adalah teknik purposive sampling. Menurut Sugiyono $(2015,152)$ sampling purposive adalah "teknik penentuan sampel dengan pertimbangan tertentu." Artinya setiap subjek yang diambil dari populasi dipilih dengan sengaja berdasarkan tujuan dan pertimbangan tertentu. Sampel pada penelitian ini yaitu, karyawan yang bekerja di semua divisi dengn jumlah sampel sebanyak 90 karyawan.

\section{HASIL}

Berdasarkan data yang diperoleh memperlihatkan gambaran dari reponden penelitian dari jenis kelamin dari 90 orang terbagi menjadi 52 orang laki-laki dan 38 orang perempuan. Ini sejalan dengan operasi perusahaan yang menjdi objek penelitian yang lebih banyak membutuhkan tenaga laki-laki ketimbang perempuan. Sementara itu, dilihat dari faktor usia responden menjelaskan bahwa usia responden terbanyak berada di usia 31-40 tahun yang berjumlah 43 orang atau sebesar 47,8 persen, sementara usia paling sedikit adalah di angka 41-50 tahun berjumlah 8 orang atau sebesar 8,9 persen. Di karenakan usia diantara 31-40 tahun mengalami pembaruan teknologi sehingga lebih mengutamakan umur antara 31-40 tahun karena sudah lebih berpengalaman.

Bila dilihat dari jenjang pendidikan, responden penelitian terdistribusi pada yang paling tinggi adalah jenjang S1 sebanyak 53 orang atau 58,9\%, kemudian responden dengan pendidikan terakhir D3 yaitu sebanyak 20 orang atau $22.2 \%$, lalu responden dengan pendidikan terakhir SMK yaitu sebanyak 12 orang atau $13,3 \%$, responden, terakhir adalah SMA yaitu sebanyak 5 orang atau $5.6 \%$ responden. Sedangkan, disisi pengalaman, lamanya bekerja di perusahaan memperlihatkan bahwa responden yang bekerja antara 1-5 tahun berjumlah 29 orang atau sebesar $32,2 \%$, rentang lama bekerja antara 6-10 tahun berjumlah 53 orang atau sebesar $58,9 \%$ dan pada rentang lama bekerja antara $11-15$ tahun berjumlah 8 orang atau sebesar $8,9 \%$.

Untuk kepentingan analisis lebih lanjut, khususnya penggunaan analisis regeresi berganda maka data-data yang sudah dikumpulkan di uji validitas dan reliabilitasnya serta asumsi klasik yang tersedia. Dan hasilnya memperlihatakan bahwa semua indikator dari variabel independen yaitu lingkungan kerja, self-efficacy dan karakteristik peserta pelatihan, serta variabel dependen yaitu transfer pelatihan mempunyai $r$ hitung positif dan $r$ hitung $>r$ tabel. Sehingga dapat disimpulkan bahwa semua indikator dalam penelitian ini valid yang dalam artian setiap instrumen bisa pergunakan untuk mengukur apa yang seharusnya diukur dan memperlihatkan bahwa nilai signifikansi. Sig. (2-tailed) sebesar 0.200, sehingga dapat disimpulkan bahwa data tersebut berdistribusi normal karena Asymp. Sig. (2-tailed) >0.05.

1Untuk menguji hipotesis penelitian menggunakan uji t statistic dengan hasil seperti tabel berikut : 
Tabel 1 Hasil Uji t

\begin{tabular}{|c|c|c|c|c|c|c|}
\hline \multirow{2}{*}{\multicolumn{2}{|c|}{ Model }} & \multicolumn{2}{|c|}{$\begin{array}{l}\text { Unstandardized } \\
\text { Coefficients }\end{array}$} & \multirow{2}{*}{$\begin{array}{l}\text { Standardized } \\
\text { Coefficients } \\
\text { Beta }\end{array}$} & \multirow[b]{2}{*}{$t$} & \multirow[b]{2}{*}{ Sig. } \\
\hline & & B & Std. Error & & & \\
\hline \multirow[t]{4}{*}{1} & (Constant) & .935 & .894 & & 1.046 & .298 \\
\hline & TotalLK & .503 & .086 & .825 & 5.877 & .000 \\
\hline & TotalSE & 329 & .109 & .338 & 3.030 & .003 \\
\hline & TotalKPP & -.434 & .095 & .657 & -4.571 & .000 \\
\hline
\end{tabular}

Dengan tabel hasil uji $t$ diatas menunjukkan bahwa hipotesis lingkungan kerja, self-efficacy, karakteristik peserta pelatihan terhadap transfer pelatihan karyawan adalah :

1. Nilai sig pada variabel lingkungan kerja sebesar 0.000 dimana nilai tersebut < 0,05 , maka dapat disimpulkan bahwa Ho tidak dapat diterima, artinya variabel lingkungan kerja berpengaruh secara signifikan terhadap variabel transfer pelatihan.

2. Nilai sig pada variable self-efficacy sebesar 0.003 dimana nilai tersebut < 0.05 , maka dapat disimpulkan bahwa Ho tidak dapat diterima, artinya variabel self-efficacy berpengaruh secara signifikan terhadap variabel transfer pelatihan.

3. Nilai sig pada variabel karakteristik peserta pelatihan sebesar 0.000 dimana nilai tersebut $<0,05$, maka dapat disimpulkan bahwa Ho tidak dapat diterima, artinya variabel karakteristik peserta peltihan berpengaruh secara signifikan terhadap variabel transfer pelatihan.

\section{PENUTUP}

Berdasarkan hasil analisis dan uji hipotesa maka dapat dibuat simpulan penelitian ini, adalah bahwa ada pengaruh yang signifikan variabel lingkungan kerja, self efficacy dan karakteristik peserta pelatihan terhadap transfer pendidikan karyawan pada perusahaan yang menjadi obyek penelitian. Dan oleh karena itu, agar pelatihan yang diikuti dapat diterapkan oleh karyawan dalam pekerjaanya, maka perusahaan perlu memberi perhatian pada tiga variabel kunci yaitu lingkungan kerja, self-efficacy,d an karakteristik peserta pelatihan. 


\section{REFERENCES:}

Abdullah, Dayang Nailul Munna Abang dan Jicky Chaong Suring. 2011. The Relationship between Motivation to Transfer, Training Design, Transfer Climate and Transfer of Trainin. International Conference on Ebusiness, Management and Economics, Vol 3, No. 335-339.

Bhatti, Muhammad Awais., Mohamed Mohamed Battour., Veera Pandiyan Kaliani Sundram., dan Akmal Aini Othman. 2013. Transfer Of Training : Does It Truly Happen ? An Examination Of Support, Instrumentality, Retention adn Learner Readiness On The Transfer Motivation and Transfer Of Training. European Journal Of Training and Development, Vol 37, No 3. pp :273-297.

Colquitt, Jason A., Jeffrey A. LePine dan Raymond A. Noe. 2000. Toward Integrative Theory Of Training Motivation : A Meta-Analytic Path Analysis of 20 Years of reseacrh. Journal of Applied Psychology, Vol, 85 : hal 678707.

Cromwell, S. E. and Kolb, J. A. 2004, 'An examination of work-environment support factors affecting transfer of supervisory skills training to the workplace', Human Resource Development Quarterly, 15, 449-71

Ford, J.Kevin dan Daniel A. Weissbein. 1997 . Transfer of Training: An Update Review And Analysis. Performance Improvement Quarterly, 10(2) pp. 22-41.

Hutchins, Holly M. 2009. In the Trainer's Voice : A Study of Training Transfer Practices. Performance Improvement Quarterly, pg. 69.

Kilapong, Samuel N. 2013. Kepemimpinan Transformasional, Self Efficacy, Self Esteem Pengaruhnya Terhadap Kepuasan Kerja Karyawan PT.Tropica Cocoprima Manado. Jurnal EMBA, Vol.1 , No.4, Hal. 141-150.

Maung, KhinMarlar dan Sujinda Chemsripong. 2014. Work Enviroment Factors Influence On Transfer Of Training In Myanmar.South East Asia Journal of Contemporary Business, Economics And Law, Vol. 4, Issue 1 (June) ISSN 2289-1560.

Tziner, Aharon. Michal, Fisher. Tami, Senior and Jacob Weisber. 2007. Effects of Trainee Characteristics on Training Effectiveness. International Journal of Selection and Assessment. Vol.15, No.2.

Saleh, Khairul. 2012. Pengaruh Locus of Control,Orientasi Tujuan Pembelajaran dan Lingkungan Kerja terhadap Self-Efficacy dan Transfer Pelatihan Peningkatan Kompetensi Guru Madrasah Aliyah (MA) seKaresidenan Semarang. Ragam Jurnal Pengembangan Humaniora Vol. 12 No. 1. 
